\title{
Korsets gåde - en undersøgelse af offerbegrebets filosofiske og teologiske implikationer
}

\author{
Cand.mag., stud.theol. \\ Annette Hjort Knudsen, Kobenhavns Universitet
}

\begin{abstract}
According to Asle Eikrem's book "God as Sacrificial love", the concept of the Christian God as a God of love is not coherent with the claim that Jesus was sacrificed on the cross for the redemption of human sins. Eikrem's conclusion builds on a conceptual framework that describes the crucifixion as a self-sacrifice. His argument makes Jesus co-responsible, thus sanctioning the violent action. This way, evil becomes instrumental which is inconsistent with the notion of God as love. It is the intention of this article to show that (at least) one alternative conceptual framework makes it possible to maintain the view that the crucifixion was necessary for Jesus' redemptive mission. The crucifixion is thus not inconsistent with, but rather a consequence of the conception of God as love. For Jesus to realize God's incarnational intention of establishing a living fellowship with humanity is for him to realize a fellowship of experienced damnation followed by a truly redemptive resurrection.
\end{abstract}

Keywords: Asle Eikrem - coherence - language - sacrifice - redemption - crucifixion - humanity - love - sin - ethics.

\section{Korsets gåde - en undersøgelse af offerbegrebets filosofiske og teologiske implikationer}

Korset er et bærende symbol for den kristne tro og helt centralt for den kristne forsoningslære: Guds søn korsfæstes for vore synders skyld. ${ }^{1}$ Men hvordan skal dette offer forstås, og hvordan kan et blodigt offer åbenbare en kærlig Gud? Hvordan er det muligt at fastholde korsets offer som en nødvendig betingelse for frelsen og samtidig fastholde Gud som kærlighed? Det er det centrale spørgsmål i Asle Eikrems

1. Forsoningslæren er naturligvis ikke en entydig størrelse, jf. Aulens typologier, men korset indgår i dem alle, som den centrale begivenhed. 
bog "God as Sacrificial love". ${ }^{2}$ Eikrem besvarer spørgsmålet negativt: Det er ikke muligt at fastholde både korsets nødvendighed og Guds kærlighed uden at rode sig ud i et logisk inkohærent standpunkt, der gør gudsbegrebet meningsløst. Teologer bør derfor ifølge Eikrem ikke medtænke korset i frelsesforstålsen men holde sig til inkarnationen og opstandelsen som tilstrækkelige betingelser. For at kunne fastholde Gud som kærlighed konkluderer Eikrem om korset, at "it would have been better without it" (Eikrem 2018, 108). At hævde andet vil være logisk inkohærent.

Eikrems bog blev anmeldt af Harald Hegstad i Teologisk Tidsskrift, ${ }^{3}$ hvor den efterfølgende har givet anledning til en debat mellem Hegstad og Eikrem om både Eikrems metode og teologiske konklusioner. Hegstad indvender bl.a. at Eikrem gør sig opgaven for let ved simpelthen at forkaste korset, snarere end at forsøge at forstå, hvad der teologisk set er på spil. "I stedet for å forsøke å gi mening til korset, hevder han at korset slett ikke var nødvendig ... i stedet for å forsøke å løse knuten, hugger han den over. I stedet for å forsøke å belyse mysteriet, risikerer han å avlyse det" (Hegstad 2019, 54). Det er ifølge Hegstad ikke at løse, men at svigte den teologiske opgave, som ikke kun er forpligtet på kohærens, men også på troens centrale symboler.

Eikrems afvisning af korsets betydning hviler på en begrebsanalyse, der demonstrerer standpunktets inkohærens. I debatten med Hegstad efterlyser Eikrem derfor en alternativ analyse af korsets begivenhed, der både lever op til kravet om kohærens og fastholder korsets nødvendighed for menneskets frelse. ${ }^{4}$ Det er muligheden af en sådan alternativ analyse, der er denne artikels anliggende.

\section{Offerbegivenhedens passive og aktive momenter}

I Eikrems forstålse af offerbegivenheden er offeret passivt. Hvis offeret spiller en aktiv rolle, er det fordi, det helt eller delvist stiller sig på

2. Asle Eikrem, God as sacrificial love. A Systematic Exploration of a Controversial Notion. T\&T Clark Studies in Systematic Theology (London/New York: Bloomsbury Academic 2018). Eikrem giver et udførligt overblik over forsoningslærens udvikling og typer i bogens kapitel 2.

3. Harald Hegstad, "Var korset nødvendig? En vurdering av Asle Eikrems bok om Jesu død som offer", Teologisk tidsskrift 8 (2019), 41-54.

4. Asle Eikrem, "Mer korsteologi - Ny replikk til Hegstad!", Teologisk tidsskrift 9 (2020), 52-58 (53): "Slik jeg ser det, står altså valget mellom troen på en fullkomment god Gud og troen på en Gud som velger korset for å frelse menneskeheten. Som kristen teolog med en ambisjon om å tenke koherent om Gud, mener jeg at det å avvise førstnevnte korstolkning er det minst problematiske alternativet. Hegstads utfordring er å vise hvordan det motsatte lar sig gjøre.” 
bødlens side og deltager aktivt i sin egen passive ofring (self-sacrifice, self-victimization etc.). Den ofrede kan ikke som offer spille en aktiv, definerende rolle i beskrivelsen af fænomenet - det ofres og indgår i den forstand som rent passivt element i den fænomenologiske beskrivelse. ${ }^{5}$ Denne fænomenologiske analyse har som teologisk konsekvens, at der heller ikke i korsets offer kan ses andre aktive kræfter end de destruktive. Ved at lade sig ofre, har Jesus stillet sig på bødlens side og sanktioneret hans handling. Hermed åbenbarer han en blodtørstig Gud, som ikke er foreneligt med den kristne forståelse af Gud som god, og som samtidig legitimerer fortsatte overgreb og selvofringer (fx kvinder, der tåler og bærer deres egen undertrykkelse ${ }^{6}$ ). Eikrems etiske analyse af korsets ondskab bliver til en teologisk konklusion om dets umulighed. Det bliver derfor afgørende for Eikrem at udvikle en systematisk teologi, der omdefinerer korsets betydning, så det ikke er centralt for frelsen, men blot en beklagelig biting ved inkarnationen. At Kristus dør og genopstår er ifølge Eikrem tilstrækkeligt for frelsen, hvorimod måden, han dør på, ikke har relevans.

I det efterfølgende er det intentionen at påvise, at det er muligt at beskrive fænomenet "offer" med et alternativt analytisk begrebsapparat, der muliggør en kohærent forståelse af offer-begivenheden, uden at Gud bliver forstået som blodtørstig og uden at legitimere overgreb og påbyde ofret at tåle dem i en misforstået "efterfølgelse" af Kristi lidelser. Fremfor som Eikrem at se offerfænomenet som et aktivt overgreb overfor en passiv lidelse, bliver fænomenet - med udgangspunkt i Sigrid Brandts offeraktionsskema - analyseret som sammensat af flere aktive momenter. Begivenheden defineres både af en destruktiv aktivitet (syndens moment) og en konstruktiv aktivitet (kærlighedens moment), hvor det sidste ikke bare muliggør det første og i den forstand er det primære i forståelsen af situationen, men hvor det også er det sidste, der har egentlig substantiel væren. Synden afslører sig som en parasitær eksistens. Det er kærlighedens moment, der definerer situationen som det ultimative udtryk for den synd, der er selve anledningen til inkarnationens frelsende mission.

Indledningsvis redegøres for nogle af de metodiske overvejelser, der ligger til grund for artiklen og dens diskussion med Eikrem. Herefter

5. Det er offeret som fænomen, der for Eikrem består af et aktivt og et passivt element, ikke de deltagende personer - de kan i varierende grad deltage både aktivt og passivt i fænomenet. Eikrem (2018), 116-117: "any human subject is a complex activity and passivity in relation to both suffering and violence in various situations... [it] does not mean that I draw a sharp line between victim and victimizer as distinct individuals or social locations."

6. Jf. feministiske teologier. Eikrem (2018), 13: "the domestic sphere had long suffered under the yoke of this ideal”. Se også fodnote 24. 
argumenteres der mere udførligt for det analytiske begrebsapparat, der definerer forståelsen af offerets fænomen, og denne filosofiske analyses implikationer for den teologiske forstålse af inkarnationens intention og konsekvens. Da det ud over den logiske inkohærens i høj grad er de etiske konsekvenser af det kristne offerbegreb, der er anledningen til Eikrems indvendinger, undersøges det afslutningsvis, hvilke etiske konsekvenser der følger af de filosofiske analyser og teologiske forståelser. Er det på baggrund af den fænomenologiske undersøgelse kohærent at hævde, at korsfæstelsen afslører en ond Gud, der legitimerer fortsatte overgreb og menneskelig selvhævdelse på andres bekostning i kristendommens navn? - eller åbenbarer korsfæstelsen en kærlig Gud? Er det kohærent at hævde kristendommen som en tro, der frelser og kalder til modstand mod overgreb og undertrykkelse på grund af snarere end på trods af korset?

\section{At bedrive systematisk teologi - metodiske overvejelser}

Et af de væsentligste uenigheder i diskussionen mellem Hegstad og Eikrem handler om Eikrems metode. For Eikrem er den filosofiske kohærens det afgørende sandhedskriterie. Hvis traditionen eller de bibelske tekster ikke lader sig inkludere i en filosofisk kohærent argumentation for deres betydning og indhold, har de ikke noget selvstændigt krav på sandhed: "A theological statement is not true simply because it is truly biblical. It is true insofar as it is possible to integrate it into a theological construal more coherent than its alternatives. A criterion of authenticity must not be confused with a criterion of truth" (Eikrem 2018, 87). Heroverfor indvender Hegstad, at man ud over den filosofiske kohærens også må forlange, at tolkningen kan rumme kristendommens bærende symboler. En nok så kohærent livstydning, der ikke rummer disse symboler, har ifølge Hegstad ingen relevans for en kristen teologi. Hegstad ser derfor Eikrems bidrag "mer som et alternativ til kristen teologi enn som et bidag til en slik teologi" (Hegstad 2019, 53). 
Den systematiske teologis opgave

I sin fremhævelse af kristendommens trossætninger som afgørende forståelsesrammer for enhver systematisk teologi er Hegstad på linje med Wolfhart Pannenberg:?

der Wahrheitsanspruch der christlichen Botschaft von Gott [bleibt] unvermeidlicherweise strittig. Daran kann auch die Theologie nichts ändern. Die Theologie kann den Glauben nicht ersetzen. Aber sie kann zu klären versuchen, inwieweit sich der Glaube, dem Wahrheitsanspruch der christlichen Verkündigung entsprechend, im Bunde mit der wahren Vernunft wissen darf. (Pannenberg 2015, 477)

Opgaven for den systematiske teologi har derfor to sider, der er gensidigt forpligtende:

\section{Troens indhold $\longleftrightarrow$ systematisk udredning}

På den ene side er den kristne tros symboler og trossætninger så umiddelbart paradokse og vanskelige at forstå, at de ikke kan stå uformidlet - deres budskab vil altid være et spørgsmål om tolkning, og her spiller kohærens og begrebslig sammenhæng naturligvis en afgørende rolle, hvis fortolkningen overhovedet skal være meningsfuld. Samtidig må den systematiske teologi ikke gøre sig sagen for let og simpelthen forkaste, hvad der ikke passer til den umiddelbare forståelse. Kristendommens budskab og sandhed er ikke begrænset af, hvad menneskets fornuft kan sanktionere. Hvis troens indhold forstået som Kristi liv, korsfæstelse og opstandelse ikke fastholdes som afgørende for den kristne livsforståelse, er der ikke længere nogen kristendom. Den systematiske teologi må derfor, som Pannenberg udtrykker det i ovenstående citat, fastholdes på "der Wahrheitsanspruch der christlichen Botschaft", der er og bliver et trosspørgsmål. "Løsninger" på korsets gåde, der afskaffer gåden, må derfor afvises som irrelevante.

\section{Den systematiske teologis grense og foreløbighed}

Det inkommensurable forhold mellem troens indhold og fornuftens redegørelse er også et tema hos Sarah Coakley. ${ }^{8}$ Også hun anerkender behovet for at formulere troens indhold i sproglige termer for

7. Wolfhart Pannenberg, Systematische Theologie 1 (Göttingen: Vandenhoeck \& Ruprecht 2015).

8. Sarah Coakley, God, Sexuality, and the Self. (Cambridge: Cambridge University Press 2013). 
overhovedet at gøre den tilgængelig for menneskets endelige forståelseshorisont, men ifølge Coakley er dette krav om kohærens snarere en trussel end en garant for sandheden. I forsøget på at få greb om troens mening, er det ifølge Coakley en stadig fare i den systematiske teologiske praksis, at gudsforståelsen udarter til et afgudsforhold, når de systematiske pointer gøres "ortodokse” og uomgængelige. ${ }^{9}$ I hendes eget bud på en "théologie totale" beskriver Coakley derfor den systematiske teologi som en uafsluttelig praksis i en fortsat åben og sproglig såvel som kontemplativ omgang med sit eget anliggende, snarere end som en filosofisk disciplin, der når frem til et indiskutabelt resultat. Som det formuleres hos Coakley:

So theology's reason, at a profound level, is in ongoing contrapuntal relation to revelation and grace, and continues to be transformed by it. But - rather differently, and at another level - theology's reason also remains in contrapuntal discussion with secular philosophy and science; for it cannot rule out the possibility that here, too, it will need to learn something by which it may be changed. (Coakley 2013, 89)

Denne understregning af enhver systematisk teologis foreløbighed, utilstrækkelighed og iboende fare for at reducere det trosindhold, der undersøges, for at få det til at passe med menneskets krav om forståelse er helt afgørende for Coakleys forståelse af den systematiske teologis bidrag til menneskets guds- og selvforståelse. Også for Coakley er begge sider af Pannenbergs ligning forpligtet på hinanden, og samtidig er begge sider begrænset af sprogets endelighed, når de forsøger at formulere og indfange Guds væsentlige uendelighed. For Coakley er fastholdelsen af korsets gåde ikke udtryk for ukritiskt og fromt at "bøye seg for 'korsets gåte", ${ }^{10}$ som det formuleres af Eikrem (Eikrem 2019, 200), ${ }^{11}$ men er en logisk konsekvens af en inkompati-

9. Dette er blandt andet Coakleys indvending overfor de feministiske teologier, der i deres berettigede kritik af den patriarkalske fortolkning af kristendommens symboler står i fare for at tilskrive deres egen forståelse samme absolutte karakter. Enhver systematisk tolkning skal anerkende sin egen begrænsning og fastholde en radikal åbenhed i forhold til betydningen af de systematiske bestemmelser. Coakley (2013), 84: "Hence a théologie totale refuses to reduce doctrine to a mere effect of social, political, or patriarchal conditions. For once such a reductive hermeneutics of suspicion is allowed to triumph over the (eternal, divine) invitation to charity, forgiveness, and reconciliation, a new idolatry has also triumphed: that of anger stuck in victimology, and the implicit recreation of a "God" made merely in my own image".

10. Asle Eikrem, "Korsets gåte? Respons til Harald Hegstads bokessay", Teologisk tidsskrift 8 (2019), 198-204.

11. Se også Eikrem (2018), 109, hvor Eikrem fremhæver etikken som definerende for troens muligheder: "If we for the sake of piety resign ourselves to the "mystery" 
bilitet mellem det, teologien forsøger at sige, og de midler, teologien har at udtrykke det med. De kristne symbolers paradoksale karakter skal ikke overvindes, men fastholdes som en kilde til undren og fortsat oplysning og udforskning. Coakley citerer i den forbindelse Augustin:

We are not now discussing ... possible ways of understanding the text $\ldots$ it can only be understood in ways beyond words ... it wasn't read in order to be understood, but in order to make us try to discover what prevents our understanding, and so move it out of the way, and hunger to grasp the unchangeable Word, ourselves thereby being changed from worse to better (Coakley 2013, 288 fodnote 25).

"Mysterium ist kein Rätzel" som det formuleres af Jüngel. ${ }^{12}$ Troens indhold skal ikke "regnes ud", men forbliver en udfordring til udforskning og oplysning. "Die Grenzen meiner Sprache bedeuten die Grenzen meiner Welt", som det udtrykkes med mere filosofiske termer i et berømt citat fra artikel 5.6 i Ludwig Wittgensteins Tractatus Logico-Philosophicus. ${ }^{13}$ Uanset at jeg kan erfare min verden som større, end det lader sig udtrykke sprogligt, så er den menneskelige forståelseshorisont endeligt defineret, og den kan derfor principielt ikke rumme den "sande uendelighed", som også Eikrem fremhæver med en henvisning til Hegel. ${ }^{14}$ Når Eikrem derfor i sin diskussion med Hegstad understreger, at det ikke bare er logisk konsistens, men også "en optimal mengde relevant informasjon (erfaring, påstander, data) ... [og] et optimalt antall saklige koblinger mellom de ulike elementene i teorien .... [som skal] gjensidig støtte opp under hverandre" (Eikrem 2019, 198), så peger det i retning af Coakleys respekt for grænseløshed i den religiøse "erfaring, påstander, data”, der må respekteres og løbende "konsulteres" i en systematisk teologisk praksis,

of this contradiction, we would for the sake of piety cloud the distinction between good and evil".

12. Eberhard Jüngel, “Das Verhältnis von 'ökonomischer' und 'immanenter' Trinität”, Zeitschrift für Theologie und Kirche 72 (1975), 353-364 (358).

13. Ludwig Wittgenstein, Tractatus Logico-Philosophicus, (London/NewYork: Kegan Paul, Trench, Trubner \& Co/Harcourt, Brace \& Company 1922), 144. Wittgenstein anbefalede på den baggrund, at man helt afstår fra systematisk teologi som det udtrykkes i bogens afsluttende artikel 7 (162) "Wovon man nicht sprechen kan, darüber muss man schweigen". Den filosofiske indsigt bag dette citat kan være væsentligt at fastholde, når den systematiske teologi alligevel gør forsøget.

14. Eikrem trækker selv på denne hegelske bestemmelse af det "sandt uendelige" Eikrem (2018), 216: "God is the ultimate medium that holds every difference together", endvidere 251: "Divine love is not an identity constituted of difference, but a unity of the different living freely with, from and for each other ... With his concept of the 'true infinite', Hegel attempted to elaborate this perspective". 
der tager sin teologiske sandhedssøgen alvorligt. Systematisk teologi er en fælles famlen efter et sprog, der gør det muligt at formulere gudsforstålsen - hermed bidrager den til menneskets fortsatte selverkendelse og religiøse fællesskab, men den kan ikke på noget tidspunkt gøre krav på at være hverken absolut sandt (jf. Pannenberg) eller udtømmende (jf. Coakley) beskrevet.

\section{Offerbegivenheden analyseret}

Med ovenstående metodiske udgangspunkt, vil jeg i det følgende undersøge Eikrems begrebsanalytiske tolkning af offerets fænomen og søge at udvikle et alternativt, kohærent begrebsapparat, der gør det muligt at inkludere de væsentlige elementer fra den kristne tradition og trosbekendelse, som ikke finder plads i Eikrems analyse. Sigrid Brandts offeraktionsskema, der citeres af Eikrem i introduktionen til bogens kapitel 2, bidrager med vigtige analytiske afklaringer i den forbindelse.

\section{Eikrems begrebsanalyse}

Eikrems konceptuelle beskrivelse af offerets fænomenale karakter skelner mellem bødlen og offeret som på den ene side den aktivt ofrende part og på den anden side den passivt ofrede part. Både den ofrende og den ofrede part kan tage del i overgrebets aktive moment, men det er kun det destruktive element, der tilkendes aktivitet i offerets fænomenale bestemmelse, jf. det tidligere citerede i fodnote 5. På den baggrund opstiller Eikrem en række begreber, der på forskellig vis inddrager offeret $\mathrm{i}$ bødlens aktivitet, hvorefter han søger svaret på korset gåde i forståelsen af "the relation between the concept of self-sacrifice and those of victimization, self-limitation, selv-destruction, self-annihilation, self-giving and self-emptying (or kenosis)" (Eikrem 2018, 95). Ved at bestemme Jesu offer på korset som "self-sacrifice" har Jesus stillet sig på overgrebets side i handlingen. Når korset gøres til en nødvendig betingelse for menneskets frelse, sanktioneres bødlens handling, hvilket gør Gud til en "sadistic egoist" (Eikrem 2018, 107). Denne kritik rammer ifølge Eikrem alle fremførte forsoningslærer, som de typologiseres af Aulén. ${ }^{15}$ Eikrem konkluderer derfor, at korset åbenbarer en Gud, der er så fundamentalt i modstrid

15. Auléns typologier og deres betydning for Eikrems argumentation resumeres hos Hegstad (2019), 42-43. 
med den kristne forståelse af Gud som kærlighed, at korset må fraskrives enhver betydning for forståelsen af Jesu inkarnation og død: "There is no saving significance to the way Jesus died. It would have been better had it never happened" (Eikrem 2018, 108).

I en kohærent forståelse af Jesu død på korset er det som nævnt afgørende at medtænke "en optimal mengde relevant informasjon (erfaring, påstander, data)" (Eikrem 2018, 198). Uanset, at det ideelt set ville have været bedre, om korsdøden kunne være blevet sprunget over, så betyder syndens effekt på menneskers faktiske vilkår og det deraf følgende frelsesbehov, at korsdøden foregår med en faktisk nødvendighed, der ikke implicerer, at Gud må betragtes som "egoistisk sadist” (Eikrem 2018, 107). Korset åbenbarer Gud som syndens afgørende kærlige og frelsende modmagt. Korset bliver nødvendigt som en konsekvens af den synd, der er inkarnationens anledning, og den frelse, der er dens mål. For at kunne udvikle en kohærent begrebslig ramme for denne påstand, vil jeg tage udgangspunkt i Sigrid Brandts offeraktionsskema. ${ }^{16}$

\section{Offeraktionsskemaet}

Ifølge Brandt kan offerfænomenet karakteriseres ved 5 instanser, der bortset fra den 5. allerede formuleres hos Augustin:

1. Wer oder Was bringt Opfer bzw. ist verantwortlich für die Viktimisiering von Leben? Wer oder was is also Opferspender?

2. Durch wen oder welche Instanz wird das Opfer dargebracht? Wer oder welche Instanz ist Opfervollzieher?

3. Wem oder welcher Instanz wird das Opfer gebracht? Wer oder welcher Instanz ist Opferempfänger?

4. Wer oder was ist victim?

5. Wem oder welcher Instanz kommt das Opfer zugute? Wer oder was ist also Opfernutzniesser? (Brandt 2000, 251-252)

Afhængigt af, hvordan man tolker en given offersituation, kan dette skema udfyldes på flere måder. "Betydningen av et sentralt begrep som "offer" varierer for eksempel i ulike sammenhenger, og en systematisk rekonstruksjon må derfor utvikle sine egne begreper", som det formuleres af Hegstad (Hegstad 2019, 44). Brandt når ved hjælp af offeraktionsskemaet til følgende rekonstruktion af offerbegivenheden:

16. Sigrid Brandt, "Hat es sachlich und theologisch Sinn, von 'Opfer' zu reden?", Opfer: Theologische und kulturelle Kontexte, red. Bernd Janowski \& Michael Welker (Frankfurt am Main: Suhrkamp 2000), 247-81. 
Wer hat geopfert? Er selbst [Jesus]. Wen oder was hat er geopfert? Sich selbst bzw. seine leibliche Existenz. Durch wen hat er das Opfer dargebracht? Durch $(\delta 1 \alpha)$ Gottes Geist (Hebr 9,14). Wem hat er geopfert? Gott. Wem zugute hat er das Opfer gebracht? Den Menschen und der Durchsetzung von Gottes Willen.” (Brandt 2000, 271).

Günther Thomas ${ }^{17}$ bruger helt andre begreber til at karakterisere selvsamme begivenhed med:

Die Verkündigungs- bzw. Lebenspraxis Jesu riskiert einen Widerstand zu entfachen, der ihn selbst aus dem Leben drängt. Der Vollzug der Hingabe im Leben Jesu "resultiert" unter Bedingungen der Sünde in einen Prozess der "Victimisierung". Dieser Prozess der "Victimisierung" steuert auf einen Mord zu, zu dem sich die Mächte der öffentlichen Meinung, der Politik und der Religion verbünden. Das Kreuz wird so zu einem resultativen Endpunkt (Thomas 2007, 172).

Sætter man de to analyser over for hinanden efter offeraktionsskemaets logik får man følgende resultat (idet jeg i forlængelse af Thomas' analyse selv har udfyldt punkt 3 og 5):

\begin{tabular}{c|c|c}
\hline \multirow{2}{*}{ Hvem bringer offeret? } & Guds søn & $\begin{array}{c}\text { Politiske og religiøse } \\
\text { magtinstanser }\end{array}$ \\
\cline { 2 - 3 } & Brandts analyse & Thomas' analyse \\
\hline Hvem udfører offeret & Helligånden & $\begin{array}{c}\text { Politiske og religiøse } \\
\text { magtinstanser }\end{array}$ \\
\hline Hvem ofres der til? & Gud & Samfundsordenen \\
\hline Hvem ofres? & Guds søn & Jesus af Nazareth \\
\hline Til gavn for hvem? & Mennesket & Samfundsordenen \\
\hline
\end{tabular}

Afhængigt af hvilken prisme, man analyserer offerbegivenheden igennem, er der to aktive subjekter i analysen af korsets offer: Guds

17. Günther Thomas, "Das Kreuz Jesu Christi als Risiko der Inkarnation”, Gegenwart des lebendigen Christus, red, Günther Thomas \& Andreas Schüle (Lebzig: Evangelische Verlagsanstalt 2007). 
søn ofrer sig selv i Brandts analyse, mens han i Thomas' analyse er et offer for "die Mächte der öffentlichen Meinung, der Politik und der Religion”. Begge analyser må siges at være korrekte, og hvis de fastholdes som distinkte momenter i en og samme offerbegivenhed, muliggør det en systematisk forståelse af korsets offer, der gør det muligt på en og samme tid at se en åbenbaret kærlig Gud (i Brandts analyse) og et etisk uacceptabelt morderisk overgreb (i Thomas' analyse). Hvis man med andre ord skelner mellem kærlighedens livgivende, livsopretholdende moment og syndens nedbrydende, dødelige moment $\mathrm{i}$ en og samme offerbegivenhed, får man et begrebsapparat, der synliggør kærlighedens aktive modmagt til syndens overgreb, samtidig med at syndens moment fastholdes som syndigt og ondt, netop i lyset af den kærlige modmagt, der fordømmer den. ${ }^{18}$

\section{Kerlighed og synd som aktive momenter}

Både "Me too" bevægelsen og "Black Lives Matter" har aktuelt givet anledning til en del debat om forholdet mellem offer og bøddel. ${ }^{19}$ En debat, der blandt andet har udfordret den traditionelle modstilling af en aktiv bøddel over for et passivt offer - ikke i den forstand at offeret er medskyldigt i overgrebet, men i den forstand, at der altid også er en modsatrettet aktivitet på spil: uanset hvilken ydre form, denne modstand antager, er der i ethvert overgreb en modsatrettet kraft på spil en aktiv, konstruktiv bevægelse, der sigter mod at bevare ofrets liv og værdighed uanset den umiddelbare afmagt i situationen. Denne klare identifikation og adskillelse af to aktive momenter muliggør en mere sammensat fænomenologisk beskrivelse af offerfænomenet, der sætter os i stand til at fastholde overgrebet som ondt og livsnedbrydende (syndens moment) og offerets modmagt som god og livsopbyggende (kærlighedens moment).

Adskillelsen af disse modsatrettede kræfter kan bidrage til en forståelse af korsfæstelsen, der fastholder mordet som synd og samtidig muliggør, at Guds søns aktive og kærlige modmagt bliver det afgørende frelsende element i begivenheden. René Girard ville i den

18. Når Jesus i Johannesevangeliet (19:30) tilskrives slutordene "Det er fuldbragt", i Lukasevangeliet "Fader, i dine hænder betror jeg min ånd" (23:46), hvorimod han i Markusevangeliet $(15,34)$ og Matthæusevangeliet $(27,46)$ citeres for slutordene "Min Gud, min Gud! Hvorfor har du forladt mig" hvorefter han udånder med et højt skrig, så kunne disse slutord tolkes som fuldbyrdelsen af hhv. kærlighedens (Joh og Luk) og syndens moment (Mark og Matt).

19. Se fx Chris Pool \& Ditte Bjerregaard, "Drop myten om den passive kvinde. Kvinder siger hver dag fra over for voldelige mænd”, Dagbladet Information, 24. august 2020; Mikkel Thorup, “Tænkerne bag Black Lives Matter”, Dagbladet Information, Bogtillagget 18. september 2020. 
forstand få ret $\mathrm{i}$, at "Sacrifice is simultaneously a murder and a most holy act” (Eikrem 2018, 68). Denne fænomenologiske bestemmelse af offerbegivenhedens to aktive momenter underbygges også af Mikkel Gabriel Christoffersens analyse af lidelsen som en afledt tilstand, der er helt afhængig af den værdi, der tilskrives det, som mistes: "God who shared in creaturely vulnerability, through the incarnation, demonstrates a movement of love that values creaturely life in the midst of vulnerability" ${ }^{20}$ Eller, som Christoffersen understreger det med et citat fra Jürgen Moltmann: "Primär erfahren wir das Leben und die Liebe zum Leben und erst danach den Verlust des Lebens und der Menschen, die wir lieben " (Christoffersen 2018, 143 fodnote 460). Det er kærlighedens moment, der giver overgrebet sin bestemmelse (eller dom) som synd, ligesom det er værdien i livet, der giver lidelsen sin smerte. Uden denne værditilskrivning var der ikke noget tab. I den forstand kommer det livgivende princip før det nedbrydende, idet det sidste kun kan finde sted, så længe der er noget at bryde ned, hvorimod det skabende liv eksisterer i sin egen ret og kraft. Gregor af Nyssa $^{21}$ er inde på det samme, når det understreges, at

ondskab [er] en modsætning til dyd, ikke fordi ondskab er et væsen i sig selv, men fordi den opfattes som fravær af det gode. Ligesom vi siger, at blindhed er modsætning til synet, ikke fordi blindhed af natur er til i sig selv, men fordi det er berøvelsen af noget, man har haft, således siger vi, at ondskab må betragtes som berøvelsen af det gode (Nyssa 2007, 175).

Synden kan nedbryde livet - og der er næppe et tidspunkt i verdenshistorien, hvor syndens principielle mulighed ikke også er realiseret virkelighed - men den har hverken det første eller det sidste ord og bliver derfor, uanset hvor overmægtig den måtte forekomme i situationen, aldrig det egentlig definerende. I den optik kan Guds død på korset i Kristi inkarnerede skikkelse ses som syndens kulmination, da den er op imod selve den fundamentale skaberkraft, som den er parasitært afhængig af. Det er ikke bare endnu et menneske som så mange andre, der både før og efter korsfæstelsen har været offer for syndens overgreb - det er kærlighedens væsen, Guds evige Logos og levende ord, som synden vil til livs. Selvsamme kærlighed og skabende livsprincip, som synden har sin parasitære og destruktive eksistens ved. I den forstand kan dramaet på korset, som det meget præcist for-

20. Mikkel Gabriel Christoffersen, Living with Risk and Danger. Studies in Interdisciplinary Systematic Theology. (Københavns Universitet: ph.d.-afhandling 2017), 143.

21. Gregor af Nyssa, "Den kateketiske tale", Gregor af Nyssa oversat af Jørgen Ledet Christiansen (København: Forlaget Anis 2007), 161-233. 
muleres af Jüngel, betragtes som en absolut begivenhed, "eine Einheit von Leben und Tod zugunste des Lebens” (Jüngel 1975, 353).

\section{Inkarnationens frelsende mission}

Det følger naturligvis ikke uden videre af analysen af korsfæstelsens to aktive momenter, at sammenstødet på korset var nødvendigt for menneskets frelse. Gud kunne jo principielt have valgt at frelse mennesket på anden vis. Som Eikrem formulerer det:

God has the capacity to lift people out of their sin without the need for a vicarious suffering of the death-penalty ... Gods mission to re-establish a living fellowship between humanity and God ... is co-extensive with the incarnation ... a theology of the cross must ... connect the meaning of Jesus's suffering and death to his pre-Easter ministry and his resurrection ... Jesus was not born only to be murdered (Eikrem 2018, 90- 91).

Eikrem drager på den baggrund den radikale konklusion, at "The blood shed on the cross was not constitutive of the meaning of his redemptive mission, but its contingent and tragic consequence. Jesus was no saviour because of the cross, but despite the cross" (Eikrem 2018, 75). En kohærent hævdelse af korsets nødvendige eller kontingente karakter er således ikke kun et spørgsmål om, hvordan man forstår korsfæstelsen som et offer, men også om, hvordan man forstår "the meaning of his redemptive mission".

Med en lettere omskrivning kan Brandts aktionsskema benyttes som analytisk værktøj til at forstå, hvilke aspekter der er konstituerende for forståelsen af Jesu "redemptive mission": hvem frelses? fra hvad? af hvem? hvorfor? Hvad indebærer "Gods mission to re-establish a living fellowship between humanity and God" (Eikrem 2018, 91), og i hvilken forstand er korset et kontingent eller nødvendigt element i den mission?

Ifølge aktionsskemaets logik er det mennesket (hvem frelses), der skal frelses fra synden (fra hvad), og Guds søn (af hvem), der skal gøre det ved at inkarneres (hvordan) i skikkelse af Jesus af Nazareth og dermed dele skæbne med det menneske, der er elsket af Gud (hvorfor), og som det hele derfor handler om. Spørgsmålet om, hvordan frelsen sker, bliver derfor et spørgsmål om, hvorvidt korset er en konsekvens af inkarnationens hensigt om at møde mennesket i dets faktiske syndige livsvilkårs yderste konsekvens, eller om den frelsende mission 
kan gennemføres uden en sådan konfrontation med syndens virkelighed, som det sker på korset.

\section{Det nødvendige og det tilstrakkelige}

"Jesus was not born only to be murdered" (Eikrem 2018, 91 - min kursivering), og korset må derfor forstås i lyset af både den forkyndelse, der går forud, og den opstandelse, som følger efter. Det er den forudgående åbenbaring i Jesu forkyndelse og undergerninger, der gør det muligt at forstå, hvad det er for et drama, der er på spil på korset: Det er ikke bare nok et menneske som så mange andre, der både før og efter Jesu korsfæstelse er ofre for syndens overgreb - det er kærlighedens væsen, Guds evige Logos og levende ord, som hænger på korset. Og det ved vi kun i lyset af den forudgående forkyndelse og manifestationen af kærlighedens fundamentale overmagt i opstandelsen. Korsets frelsende betydning kommer i den forstand ikke fra korset selv. At korset ikke er tilstrækkeligt betyder imidlertid ikke, at det ikke er nødvendigt for missionen om at etablere "a living fellowship between humanity and God" (Eikrem 2018, 91). Som det formuleres af Brandt:

\footnotetext{
Deutlich wird auch, dass er mit dem "Opfer" Jesu Christi nicht in erster Linie dessen Kreuzestod (!), sondern dessen Existenz im Leibe, sein leibliches Leben also zur Erfüllung von Gottes Willen meint ... es umgreift Jesu Christi Empfangen des Leibes und sein Durchleiden der Gottesferne der Menschen bis in ihre tiefste Tiefe am Kreuz, und es umgreift schliesslich Jesu Christi Eintreten in die Gegenwart Gottes" (Brandt 2000, 270f.)
}

Viljen til at inkarneres er en vilje til at gøre fælles sag med mennesket helt ud i eksistensens yderste konsekvenser - der hvor eksistensen er kuet og truet, og synden udfolder sin livsødelæggende kraft. Inkarnationens radikale, intenderede konsekvens er en "Durchleiden der Gottesferne der Menschen bis in ihre tiefste Tiefe am Kreuz". Korset kan imidlertid ikke stå alene, men skal forstås i lyset af den forkyndelse, der ligger forud, og den ultimative overvindelse af syndens virkelighed, der manifesterer sig i den efterfølgende opstandelse. Korset er ikke en tilstrækkelig betingelse for frelsen - men deraf følger ikke, som Eikrem konkluderer, at den ikke er en nødvendig betingelse. Uden korset mangler en nødvendig forudsætning for, at levende mennesker kan erfare frelsens virkelighed i deres eget konkrete liv. Uden korset er inkarnationens frelsende mission ikke fuldbragt. 


\section{Det konkrete menneske som frelsens årsag og mål}

Christoffersen gør i lighed med Brandt opmærksom på, at tilgivelsens kraft er virksom også inden korsfæstelsen og i den forstand er uafhængigt af korset: "When Jesus begins his missionary activities, he forgives sinners simply on his own authority ... Jesus then has authority all of his own to forgive sins with no other conditions being required" (Christoffersen 2017, 210). Jesu virke åbenbarer allerede inden korsfæstelsen, hvem han er. Christoffersen overser imidlertid, at hver eneste frelses- og tilgivelseshistorie i evangeliernes fremstilling er konkret situeret. Frelsen er ikke en abstrakt handlen hen over hovedet på de mennesker, den angår. Frelsen både før og efter korset er altid personligt engagerende: "din tro har frelst dig" (Luk 7,50 og 17,19; Matt 9,22). Uanset om mennesket, som den blødende kvinde, selv opsøger frelsen (Matt 9,20-22), eller den gives uopfordret, som til den lamme ved Bethesda dam (Joh 5,6-8), er tilgivelsen i hvert tilfælde situeret og historisk konkret. En sådan situeret og konkret tilgivelse er naturligvis kun mulig, sålænge Jesus er på jorden. Hvis den samme tilgivende kraft skal være personligt, konkret og situeret tilgængelig også efter Jesu død, må det gøres muligt at erfare både syndens dom og dens endegyldige overvindelse som et frisættende livsvilkår for alle mennesker til alle tider.

Gregor af Nyssa lægger i sin forståelse af frelsesbegivenheden stor vægt på, at det er levende mennesker, skabt i Guds billede, der skal frelses - ikke døde genstande uden vilje og magt til at handle. Gud må engagere mennesket i sin egen frelse, hvis det skal blive, hvad det er, og leve efter sin skabte bestemmelse. Mennesket er i den forstand både anledning til frelsens nødvendighed og målet for inkarnationens frelsende mission. I forlængelse af det tidligere citerede fremhæver Gregor af Nyssa i Den Kateketiske Tale, at "intet ondt eksisterer i sig selv uden for den frie vilje, men det får sit navn af, at det gode ikke er til” (Nyssa 2007, 178). Menneskets frie vilje er afgørende for forståelsen af den synd, som mennesket skal frelses fra - det skal dybest set frelses fra sig selv - og Gud kan derfor ikke frelse mennesket, uden at mennesket engageres aktivt og frivilligt vender sin vilje fra syndens til kærlighedens moment. ${ }^{22}$ Som det formuleres hos Nyssa: "han har ikke ved hjælp af vold og magt underkastet den menneskelige natur sit forgodtbefindende ved mod dens vilje at drage den mod det gode, som var den en ting uden sjæl” (Nyssa 2007, 178)

22. Denne påstand står ikke i modsætning til Luthers tese om, at nåden er gratis og uafhængig af menneskets indsats. Mennesket kan ikke gøre hverken fra eller til i forhold til mulighedsbetingelsen for sin egen frelse - men mennesket forbliver et levende engageret væsen, som derfor aktivt må vælge side i den stadige spænding mellem syndens og kærlighedens moment i livet. 
At det er levende, frie, aktive mennesker, der skal frelses, må naturligvis have betydning for frelsesbegivenhedens form - dens hvordan. Frelsen må have en form, der gør det muligt for mennesket at forstå sin egen splittelse mellem syndens og kærlighedens moment, ikke som en abstrakt påstand, men som konkret virkelighed. En virkelighed mennesket skal frelses fra, idet det både fordømmes (korsfæstelsens skrig) og tilgives (opstandelsens virkelighed). Hvis det er troen på kærlighedens fundamentale forrang, der frelser mennesket, må det på baggrund af offerbegivenhedens to aktivt konstituerende momenter anses for kohærent at antage, at korsfæstelsen er det nødvendige, konkrete udtryk for denne virkelighed.

Det er med andre ord ikke et abstrakt begreb om Gud ("Gud er god") men syndens faktiske virkelighed i menneskelivet, som må være udgangspunktet, når korsets begivenhed skal vurderes som nødvendig eller ej. Som Eikrem ganske rigtigt konstaterer, så gælder det, at "a theology of the cross must ... connect the meaning of Jesus's suffering and death to his pre-Easter ministry and his resurrection ... Jesus was not born only to be murdered" (Eikrem 2018, 90- 91). Jesu gerninger i livet åbenbarer, hvem han er, og hvem det er, der dør på korset, mens genopstandelsen bekræfter dette ved samtidig at stadfæste tilgivelsens substantielle og overlegne kraft. Jesus blev derfor ikke født "only to be murdered", men også for at blive slàet ihjel - i inkarnationens radikale konsekvens. Korsfæstelsens egentlige betydning følger af det forudgående virke og den efterfølgende opstandelse. Et virke der som syndens modmagt var den direkte provokerende årsag til korsfæstelsen, der med syndens logik (ikke Guds) nødvendigvis måtte føre til konfrontation, jf det tidligere citerede fra Thomas.

Det betyder selvfølgelig ikke, at Eikrem ikke har ret i, at "It would have been better had it never happened" (Eikrem 2018, 108). Det ville det selvfølgelig ud fra en ideel betragtning. Det svarer jo til at sige, at det ville have været bedre, om mennesket levede uden syndens vilkår. Det kan man jo ikke være uenig i helt indlysende ville være bedre - men det gør mennesket faktisk ikke. Syndens faktiske hærgen er et helt afgørende element af "en optimal mengde relevant informasjon (erfaring, påstander, data) ... [og] et optimalt antall saklige koblinger mellom de ulike elementene i teorien .... [som skal] gjensidig støtte opp under hverandre" (Eikrem 2019, 198). Lige fra syndens store synlige konsekvenser i klimakatastrofe, flygtningestrømme og borgerkrig til dens mere lokale udtryk i partnervold og strukturel ydmygelse af samfundets svageste gør syndens magt og selvhævdelse sig gældende og nedbryder livet for mennesker.

Det er konsekvensen af denne virkelighed, mennesket skal frelses fra. Mennesket har ingen gavn og glæde af en abstrakt tilgivelse men 
har brug for et konkret vidnesbyrd om, at kærligheden er stærkest også når den opleves som allerlængst væk. Mennesket skal kunne erfare dette som sandt i virkelighedens konfrontation med det frelsende budskab om Jesu korsfæstelse og opstandelse.

\section{Korsets etiske budskab}

Etisk set er korsets budskab, at det gode liv ikke er et spørgsmål om at leve bekvemt eller smertefrit, men om at stå på kærlighedens side og styrke den modmagt, der uophørligt er til stede og påkrævet mod syndens faktiske overgreb. Det var bedre, om det ikke var sådan, men sådan forholder det sig faktisk, og derfor må Jesus nødvendigvis dø på korset. Næstekærlighed er kernen i kristen etik, og næstekrænkelse er derfor dens modsætning. Den absolutte næstekrænkelse blev konfronteret i Jesu død på korset - en død der ikke endte med krænkelsen men med opstandelse og dermed endegyldigt stadfæstede næstekrænkelsens parasitære eksistens: den kan kun virke, hvor der er noget at krænke, og døden er derfor dens grænse. Næstekrænkelsen kan ikke virke i sig selv men kun i afhængighed af det liv, der krænkes. Livet og kærligheden derimod virker i fri uafhængighed af omstændighederne. Der kan altid elskes. I kampen mellem liv og død får livet derfor både det første og det sidste ord. Synden hersker derimellem og skal bekæmpes i sikker forvisning om, at den skade, den kan forvolde, kun er relativ. Derfor er det afgørende, at inkarnationen "umgreift Jesu Christi Empfangen des Leibes und sein Durchleiden der Gottesferne der Menschen bis in ihre tiefste Tiefe am Kreuz" (Brandt 2000, 271).

\section{Efterfolgelsens dyre nåde og den magtesløse modmagt}

Der er, som fremhævet i Mikkel Gabriel Christoffersens Ph.d-afhandling, et afgørende element af risiko forbundet med livets udfoldelse. Syndens konsekvens rammer ikke alle mennesker lige hårdt. Det er samtidig rigtigt, at risikoen for at mærke syndens konsekvens stiger betragteligt, hvis den udfordres af sin modmagt. Jesu efterfølgelse er derfor et spørgsmål om at forstå, at nåden er "dyr" - den koster konkret og faktisk i livets udfoldelse og er ikke blot en abstrakt forudsætning uden konkrete konsekvenser. Som det formuleres hos Bonhoeffer: 
Billige Gnade heißt Gnade als Lehre, als Prinzip, als System; heißt Sündenvergebung als allgemeine Wahrheit ... [und] ist darum Leugnung des lebendigen Wortes Gottes ... Billige Gnade ist Predigt der Vergebung ohne Buße ... Gnade ohne Nachfolge, Gnade ohne Kreuz, Gnade ohne den lebendigen, menschgewordenen Jesus Christus. ${ }^{23}$

Kristi efterfølgelse er et omkostningsfuldt krav om at stille sig på kærlighedens side i den uafsluttelige kamp mod syndens moment. "Damit vertiefte sich der Konflikt zwischen dem Leben des Christen und dem Leben der Welt in unabsehbarer Weise. Der Christ war der Welt auf den Leib gerückt. Es war Nahkampf. ... in ihm [wird] der Protest gegen die Welt in letzter Schärfe angemeldet." (Bonhoeffer 1989, 35) Jesu efterfølgelse opfordrer i den forstand til "a risk taking attitude to life", som det formuleres hos Christoffersen (2017, 178).

Synden levner imidlertid ikke altid plads til aktiv modstand. Christoffersen refererer til Moltmanns gengivelse af Elie Wiesels oplevelser under holocaust: "at the sight of a young boy being hanged in a concentration camp [Elie Wiesel] answered the legitimate question "where is God" with the confession "This is where - hanging here from this gallows." " (Christoffersen 2017, 151). I sin analyse af denne oplevelse understreger Christoffersen "The youngster never sought out his particular destiny of suffering ... The boy did not pursue suffering; the young boy wanted to live" (Christoffersen 2017, 151). Det er drengens vilje til liv, der giver situationen dens bestemmelse som morderisk overgreb. Også i den mest magtesløse kamp mod syndens moment gør Jesus mennesket følgeskab og bekræfter dets værdighed og den ultimative overvindelse af uretten.

Hvad enten der er tale om et afmægtigt, tavst skrig fra et barn lammet af rædsel eller lidelser som konsekvens og gengældelse for den voksnes aktive modstand, så har Kristus gjort mennesket følgeskab i dets uundgåelige kamp mod syndens aktive moment i livet. "Efterfølgelse" bliver derfor ikke et spørgsmål om at tåle smerten eller instrumentalisere bødlens overgreb ${ }^{24}$ - det bliver snarere et spørgsmål om at identificere sig med kærlighedens moment i denne uafsluttelige kamp. Det afmægtige barn er i sin afmagt fastholdt i sin menneskelige værdighed og fundamentale ret i forhold til syndens overgreb.

23. Dietrich Bonhoeffer, "Nachfolge", Dietrich Bonhoeffer Werke 4, red. Martin Kuske \& Ilse Tödt (Gütersloher Verlagshaus, 1989), 29f.

24. Jf. Eikrem (2018), 53, hvor han henviser til "liberationist and feminist voices ... emphasizing how sacrifice has been turned into a moral ideal when religiously legitimated"; "accepting unintended suffering becomes the mark of true love ... It makes the virtue of revolt against victimization morally suspect" (73), hvilket jo må siges at være "ethically unsound" (78). 
Det samme er Bonhoeffer, når han betaler prisen for sin aktive modstand mod syndens moment. Og det samme er - mere bemærkelsesværdigt - den synder, der, som det formuleres hos Jürgen Moltmann, "in der langen Schatten der Täter" 25 angrende skal forlige sig med sin egen indsats for syndens snarere end kærlighedens moment.

\section{Konklusion}

Eikrems bog er et vigtigt indlæg i den teologiske samtale. Den er en helt berettiget korrektion til en kristendom, der vil retfærdiggøre den undertryktes lidelse ved at se den som en "efterfølgelse" af Kristi tålsomhed på korset. En sådan tolkning af korset, der retfærdiggør undertrykkelsen, kalder på modsigelse. Her har Eikrems problematisering af korsets betydning en indiskutabel berettigelse.

Når kristne symboler misbruges, er der imidlertid to veje, man kan gå. Enten kan man afvise det kristne symbol som irrelevant eller måske ligefrem meningsløst. Det har været Eikrems vej. Eller man kan afvise den tolkning af symbolet, der muliggør misbruget. Det har været forsøgt i denne artikel.

Frelsen er ikke en abstrakt ide, men vedrører konkrete, levede liv. Korset var derfor lige så nødvendigt, som synden er uomgængelig. Syndens virkelighed er det, der overhovedet gør inkarnationen og frelsen nødvendig. Denne virkelighed kan ikke ignoreres, hvis frelsen skal blive en konkret erfaring. Ved at fastholde kærlighedens moment i korsets offer som det fundamentale, åbenbares kærligheden som Guds skabende og livsopretholdende væsen. Herved giver kristendommen mennesket præcis det håb og den livskraft, der opmuntrer til etisk handling og lindrer både offerets og bødlens smerte.

Om det er sandt, kan ikke afgøres ad systematisk vej (jf. Pannenberg), og den systematiske fremstilling er under alle omstændigheder helt utilstrækkelig (jf. Coakley) - men det er kohærent.

25. Jürgen Moltmann, "Gerechtigkeit für Opfer und Täter", In der Geschichte des dreieinigen Gottes: Beiträge zur trinitarischen Theologie (München: Chr.Kaiser 1991), 74-88, (81). Heller ikke hos Moltmann har denne forsoning abstrakt karakter, men manifesteres konkret, ibid (84): "Gott versöhnt diese Welt im Widerspruch durch sein Erleiden des Widerspruchs, nicht durch den Widerspruch des Widerspruchs”. 